\title{
Honeybees Dufour's gland - idiosyncrasy of a new queen signal
}

\author{
Tamar KATZAV-GoZANSKY ${ }^{\mathrm{a} *}$, Victoria SOROKER ${ }^{\mathrm{b}}$, Abraham HeFETZ $^{\mathrm{a}}$ \\ ${ }^{a}$ Department of Zoology, George S. Wise Faculty of Life Science, Tel Aviv University, \\ Ramat Aviv, Tel Aviv, Israel \\ ${ }^{b}$ Department of Entomology, ARO, The Volcani center Bet Dagan, 50250, Israel
}

(Received 8 October 2001; revised 15 April 2002; accepted 28 May 2002)

\begin{abstract}
Dufour's gland (DG) secretion of queens in Apis mellifera is normally caste specific. In queenright (QR) workers it is composed of odd $n$ alkanes, while in queens it also possesses long chain esters. However, glandular expression is plastic since queenless (QL) workers produce a queen-like secretion. Moreover, QR gland incubated in vitro produced these esters, indicating that glandular activity is regulated. We tested the hypothesis that the secretion is an egg marking pheromone. Chemical analysis of the egg coating revealed minute amounts of the queen esters, but neither queen secretion nor the synthetic esters were able to protect worker-laid eggs from policing, refuting the hypothesis. Analysis of abdominal tips further revealed that Dufour's egg secretion is also smeared on the abodominal cuticle, suggesting that its presence on egg surface may be due to passive contamination. Next, we tested the hypothesis that the secretion serves as a queen signal. Indeed queens, but not worker glandular secretion were attractive to workers.
\end{abstract}

\section{Dufour's gland / honeybee, queen-signal / caste-specificity / retinue behavior}

\section{INTRODUCTION}

Social Hymenoptera have evolved a dazzling behavioral repertoire that is mostly regulated by pheromonal signals from diverse exocrine glands of either workers or queens (Gary, 1974). Honeybees, Apis mellifera, have one of the most complex pheromonal communication systems, possessing 15 known glands that produce an array of compounds (Free, 1987; Blum, 1992). Caste-specific pheromonal communication in honeybees is known to function in mating, alarm, defense, orientation, colony recognition, and integration of colonial activities (Blum, 1992; Winston, 1987). For example, queen mandibular pheromone (QMP) exhibits caste specificity in accordance with its involvement in queen-worker interactions, serving both as a primer and a releaser pheromone regulating worker activity and physiology (Slessor et al., 1988; Winston and Slessor, 1992). Accordingly, under queenright (QR) conditions, the composition of the queen mandibular gland secretion usually differs from that of workers, possessing a series of hydroxy- and oxo-fatty acids that are absent from worker secretion. Likewise, queen feces extracts contain esters that are not found in feces of workers (Page et al., 1988), and the presence of these esters may enable workers to recognize their queen or can be used by the queen to scent mark her colony (Breed et al., 1992). Caste specificity is also expressed in the composition of the secretion produced by tissues associated with the sting apparatus (Blum et al., 1983), but thus far an association of the secretion with a particular behavior has not been verified.

\footnotetext{
* Correspondence and reprints

E-mail:katzavt@post.tau.ac.il
} 
Worker-produced pheromones are known to function for orientation (Pickett et al., 1981) alarm, and defense (Boch et al., 1962). Chemical and behavioral evidence indicates that the glandular output does not necessarily show caste-specific rigidity, but is rather plastic and adaptive. Glandular plasticity is closely linked to temporal caste determination in bees (Simpson et al., 1968). Honeybee colonies exhibit age-related division of labor, a consequence of individual bees changing tasks as they grow older. Young workers perform tasks in the hive, while the oldest bees in the colony forage outside the hive (Winston, 1992). Consequently, exocrine gland secretions show an age-based relationship associated with task. The hypopharyngeal and wax glands become enlarged in young workers shortly after emergence, reaching and maintaining their maximum size at 5 to 15 days of age, coincidental with brood rearing and comb building tasks. The two glands diminish in size and output simultaneously with the transition from comb and brood care duties to other tasks (Winston, 1992). Conversely, sting alarm pheromone production is low in young bees, and rises as the workers age (Allan et al., 1987; Boch and Shearer, 1966). Another age-dependent exocrine gland is the worker mandibular gland. When workers become guard bees or begin foraging, they produce the very odorous compound 2-heptanone in their mandibular glands, which appears to play a role as releaser of a weak alarm behavior (Shearer and Boch, 1965). Other exocrine glands that are affected by honeybee age polyethism are the head labial glands (Katzav-Gozansky et al., 2001a). Foragers contain significantly more secretion than nurse bees. In both mandibular and labial glands these differences were shown to be task rather than age dependent. Thus, glandular content seems to be affected by caste, task and the age of the bees. These effects can not always be separated, but their influence usually is hierarchical. Glandular expression is most likely endocrine regulated, as demonstrated in the $\mathrm{JH}$ regulation of the differential activity of the mandibular Koshevnikov glands (Robinson, 1985) and the hypopharyngeal glands (Huang et al., 1994). It is probable that other exocrine glands are similarly hormonally regulated, but the underlying mechanisms are still obscure.
This review focuses on the Dufour's gland, an abdominal gland ubiquitous to the Hymenoptera. The gland was first described in honey bees by Dufour in 1841 (Trojan, 1930) and although various functions were suggested for its content, it was little studied at the time. In line with its anatomic location, attached to the sting apparatus, it was suggested that its secretion acts as toxic enhancement of the venom (Carlet, 1890), lubricant for the moving parts of the sting, or neutralization of the remains of the acid secretion in the sting (Trojan, 1930; Kerr and Lello, 1962). Ultrastructural studies conducted years latter (Billen, 1987) revealed that in the honeybee, Dufour's gland opens into the dorsal vaginal wall. It was also found that there is a well-developed muscular supply inserted into the glandular duct in its most proximate region, enabling an independent control mechanism for regulating the discharge of its contents. These results led to Billen's suggestion that the gland has a reproductive function, producing a protective coating for the passing eggs. Later, Ratnieks (1995) suggested that Dufour's gland secretion serves as an eggmarking pheromone, helping police workers to discriminate queen-laid from worker-laid eggs.

\section{CASTE SPECIFIC CHEMICAL COMPOSITION}

A comparative analysis of representatives of most bee families revealed that some classes of compounds in Dufour's gland secretion may be family characteristic, such as the macrocyclic lactones for Colletidae and Halictidae. However, other classes of compounds, such as hydrocarbons and aliphatic esters of various types and chain length have a widespread distribution among the different bee families (Cane, 1983a,b; Hefetz, 1987; Hefetz et al., 1993, 1996; Oldham et al., 1994; Tengö et al., 1991; Hefetz, 1998). The honeybee's Dufour's gland possesses only two classes of compounds, hydrocarbons and esters. Recent chemical analyses of the secretion revealed that, similar to many other honeybee exocrine glands, this gland exhibits caste-specific differences (Katzav-Gozansky et al., 1997a). The queen's gland is hypertrophied and contains up to 20 times more material than that of the workers 
(Fig. 1). Among workers, the amount of secretion found in the glands of queenless (QL) egg-laying workers was at least four time higher than that of QR nurses or foragers. Qualitatively, the exudate of QR workers is composed of a homologous series of odd $n$-alkanes ranging from $\mathrm{C}_{23}$ to $\mathrm{C}_{31}$, whereas the glandular exudate of queens is also endowed with long chain esters. The main esters found in queen glandular secretion are: tetradecyl tetradecanoate, tetradecyl hexadecenoate, tetradecyl hexadecenoate, hexadecyl tetradecanoate, tetradecyl octadecenoate and hexadecyl hexadecenoate (Tab. I, Fig. 2). Wax type esters made up of tetradecanol and hexadecanol, like those identified in honeybees, have also been identified in Bombus terrestris labial glands (Hefetz et al., 1996), Bombus hypnorum head extracts (Ayasse et al., 1995), and some species of Sphecodes (Sick et al., 1994). But, with the exception of tetradecenyl dodecanoate, the esters identified in Dufour's gland are different from those identified previously in the tergal glands or feces of queens (Blum et al., 1983; Espelie et al., 1990; Page et al., 1988; Wossler and Crewe, 1999a). The hydrocarbon composition in the honeybee queen's Dufour's gland is very similar to that previously reported for both tergal glands and cuticular lipids (Francis et al., 1989; Espelie et al., 1990).

The caste specificity of the Dufour's gland expression does not seem to be rigid since under QL conditions egg-laying workers produce the queen-characteristic esters. These results suggest that the honeybee Dufour's gland, like their mandibular glands (Plettner et al., 1993), shows certain plasticity in its biosynthetic capabilities, which is apparently under queen control. Interestingly, QL foragers fail to synthesize these queen-specific esters, suggesting that this incapacity is linked to the task of the foragers; i.e., workers engaged only in outdoor activity, but it could also be linked to the age of the worker. Temporal caste structure in bees is closely linked to glandular atrophy and dystrophy (Simpson et al., 1968), implying that the biosynthetic ability is constrained by the general physiological state of the individual.

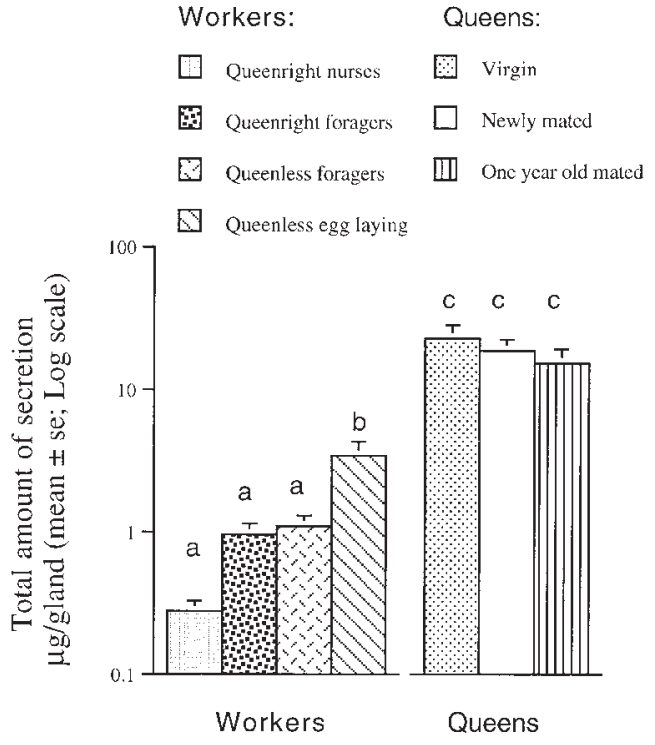

Figure 1. Total amount of volatile compounds from Dufour's gland secretion of queen and worker honeybees at various physiological states and under different social regimes. Statistical analysis was performed using ANOVA, followed by Fishers PLSD and different letters denote statistical differences at $P=0.05$. Based on Katzav-Gozansky et al., 1997 a.

\section{CASTE SPECIFIC GLANDULAR BIOSYNTHESIS}

The chemical plasticity demonstrated by honeybee Dufour's gland seems to rule out the occurrence of fixed caste-specific biosynthetic pathways and suggests an alternative hypothesis of a regulated totipotent glandular biosynthetic capability. According to this hypothesis, glandular expression is regulated by social factors (i.e., the presence or absence of the queen and/or the interactions between nest members), but may also be constrained by the workers' physiology (i.e., caste, task and reproductive state of individual bees). In an attempt to separate between these two confounding factors, we studied the de novo biosynthesis of the glandular constituents in vivo and in vitro (Katzav-Gozansky et al., 1997b, 2000). The prediction was that glandular biosynthesis in vivo will match the social situation of the individual, whereas glands incubated in vitro and therefore 
Table I. Chemical composition of Dufour's gland secretion of queens and workers of A. m. ligustica under different social regimes. To obtain an appreciable signal, analyses were carried out on pooled glands. At least 10 glands were used for each group. The results are presented as relative proportions: --- not detected $*<1 \%$; ** $1-5 \%$; *** 5-10\%;*** 10-15\%; ***** above $15 \%, \mathrm{t}=$ traces. Based on Katzav-Gozansky et al., 1997a.

\begin{tabular}{|c|c|c|c|c|}
\hline Peak No. & Compound & $\begin{array}{l}\text { Newly mated, } \\
\text { egg laying queen }\end{array}$ & $\begin{array}{l}\text { Queenright } \\
\text { nurses }\end{array}$ & $\begin{array}{c}\text { Queenless } \\
\text { egg laying workers }\end{array}$ \\
\hline & Hydrocarbons & & & \\
\hline 1 & Heneicosane & $*$ & --- & --- \\
\hline 2 & Docosane & $*$ & --- & --- \\
\hline 3 & Tricosene & $*$ & --- & --- \\
\hline 4 & Tricosane & $* * *$ & $* * *$ & $* *$ \\
\hline \multirow[t]{2}{*}{5} & Tetracosane & $*$ & --- & $*$ \\
\hline & Pentacosadien & $\mathrm{T}$ & --- & --- \\
\hline 6 & Pentacosene & $*$ & --- & --- \\
\hline \multirow[t]{2}{*}{7} & Pentacosane & $* *$ & $* * *$ & $* *$ \\
\hline & Hexacosane & --- & --- & $*$ \\
\hline 8 & Heptacosene (3 isomers) & $*$ & --- & --- \\
\hline \multirow[t]{3}{*}{9} & Heptacosane & $* *$ & $* * * * *$ & $* * *$ \\
\hline & 13 Me heptacosane & $*$ & --- & --- \\
\hline & Octacosane & --- & --- & $* *$ \\
\hline 11 & Nonacosene & $*$ & --- & --- \\
\hline \multirow[t]{2}{*}{12} & Nonacosane & $* *$ & $* * * * *$ & $* * * *$ \\
\hline & Triacontane & --- & --- & $*$ \\
\hline 14 & Hentriacontene (3 isomers) & $* *$ & --- & --- \\
\hline 15 & Heintriacontane & $* *$ & $* * * * *$ & $* * * *$ \\
\hline 18 & Tritriacontadiene (2 isomers) & $\mathrm{T}$ & --- & --- \\
\hline \multirow[t]{4}{*}{19} & Tritriacontene (2 isomers) & $* *$ & $*$ & --- \\
\hline & Tritriacontane & $\mathrm{T}$ & --- & --- \\
\hline & Penatriacontane & $\mathrm{T}$ & --- & --- \\
\hline & Esters & & & \\
\hline 10 & Tetradecyl (Z)-9-tetradecenoate & $\mathrm{T}$ & --- & --- \\
\hline 13 & Tetradecyl tetradecanoate & $* * * * *$ & --- & $* * *$ \\
\hline 16 & $\begin{array}{l}\text { Tetradecyl (Z)-9-hexadecenoate }+ \\
\text { Tetradecyl (Z)-11-hexadecenoate }\end{array}$ & $* * *$ & --- & $* * *$ \\
\hline 17 & $\begin{array}{l}\text { Tetradecyl hexadecanoate }+ \\
\text { Hexadecyl tetradecanoate }\end{array}$ & $* * * * *$ & --- & $* * *$ \\
\hline 20 & Hexadecenyl hexadecenoate & --- & --- & --- \\
\hline 21 & Tetradecyl (Z)-9-octadecenoate & $* * *$ & --- & $* * *$ \\
\hline 22 & Hexadecyl (Z)-9-hexadecenoate & $* * *$ & --- & --- \\
\hline 23 & Hexadecyl hexadecanoate & $* *$ & --- & --- \\
\hline 24 & Hexadecyl octadecanoate & $* *$ & --- & --- \\
\hline
\end{tabular}




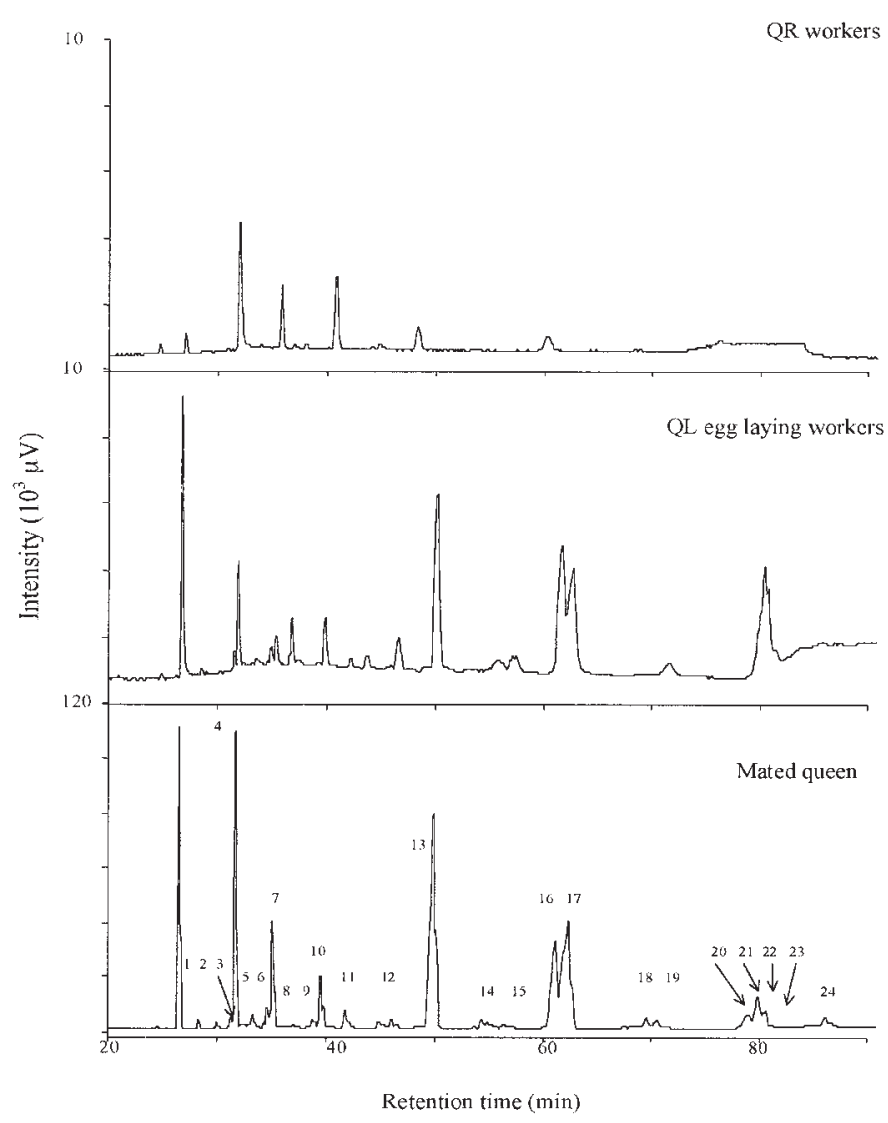

Figure 2. Gas chromatograms of Dufour's gland secretions of A. $m$. ligustica queenright $(\mathrm{QR})$ workers, queenless $(\mathrm{QL})$ egg-laying workers, and mated queens. Peak numbers correspond to the compounds in Table I. Based on KatzavGozansky et al., 1997a. detached from any endogenous or exogenous factors, would show the unregulated glandular capability. The results of these experiments confirmed the above prediction. De novo biosynthesis of the glandular constituents in vivo was in agreement, qualitatively and quantitatively, with the chemical composition of the gland in queens and in the various types of workers. Among queens, two different groups could be discerned with respect to the total amount of newly synthesized secretion and relative proportions of its constituents. Virgin queens, both non-reproductive and those induced to lay unfertilized eggs by $\mathrm{CO}_{2}$ treatment, synthesized higher levels of lipids than mated egg-laying queens, irrespective of their age. They also synthesized more esters than hydrocarbons. These changes suggest that upon mating there is a shift in the glandular expression. Comparing the chemical nature of the newly synthesized compounds, queen gland contained both esters and hydrocarbons, whereas in QR worker glands only newly synthesized hydrocarbons were found. QL egg-laying workers synthesized both esters and hydrocarbons, emphasizing that glandular plasticity is also reflected in the biosynthesis studies.

The biosynthetic picture in vitro was drastically different from that in vivo. None of the glands, from queens or workers, showed in vitro incorporation of radioactivity into hydrocarbons (Katzav-Gozansky et al., 2000). We can rule out the possibility that this glandular deficiency is caused by the lack of precursors for hydrocarbon biosynthesis since there is a similar precursor requirement for the biosynthesis of esters (Stanley-Samuelson et al., 1988). We postulate that Dufour's hydrocarbons are synthesized elsewhere, probably in the fat body, 
and that the gland sequesters them in a specific manner. Reports that hydrocarbon sequestration by exocrine glands occur also in other insects; e.g., in ants (Soroker et al., 1994) and arctiid moths (Schal et al., 1998), which support the sequestration hypothesis.

The production of esters in queen gland in vitro is again in accordance with the chemical composition of the gland. In workers, in contrast to the in vivo system, newly synthesized esters were present in the glands incubated in vitro, irrespective of the origin of the workers from which the gland was retrieved. Ester biosynthesis was very conspicuous in QR nurses and QL egg-laying workers, and to a minor degree in foragers (both QR and QL). The in vitro system also revealed a possible activation or restoration of the glandular activity once it was removed from intrinsic and extrinsic inhibitory factors. In glands of QR workers, there was a burst of radioactive alcohols within a short incubation period that declined when the incubation period was prolonged. This decline was accompanied by an increase in radioactive esters, suggesting that these alcohols are the precursors of the esters. Indeed, GC/MS analyses confirmed the presence of at least two of the primary alcohols identical to the alcoholic moiety of the major esters found in the gland. In QL egg-laying workers and queens, only small amounts of alcohols were detected, lending credence to the suggestion that all the intermediates and enzymes are already present in the gland of these bees and enable immediate ester biosynthesis.

Caste biosynthetic plasticity similar to that occurring in Dufour's gland is also apparent in the mandibular glands. Young queens' mandibular glands contain 10-hydroxy 2-decenoic acid (10-HDA, a typical worker compound), whereas workers' glands under some conditions produce 9-oxo-2-decenoic acid (9-ODA, a typical queen substance) (Crewe and Velthuis, 1980; Plettner et al., 1993; Slessor et al., 1990). Studies revealed that the $\omega$ - and $(\omega-1) 8$ - and 10-carbon fatty acids are biosynthesized in the mandibular glands in a branched, three-step pathway. Caste-specific differences in $\beta$ - and hydroxy group oxidation steps in the biosynthetic pathway lead to the unique chemical signature of the workers and queens. Although these compounds are produced via disparate biosynthetic pathways, both pathways exist in queens and workers but are apparently differentially expressed (Plettner et al., 1996). Although the biosynthetic pathway of esters in Dufour's gland is unknown, it can be hypothesized that it is similar to pathways known in other insects. Insect hydrocarbons and esters are formed by elongation of fatty acids to very long chain components (very long chain acyl groups) that are then modified to yield final products (StanleySamuelson et al., 1988). Ester biosynthesis then proceeds through the reduction to alcohols, which are subsequently esterified by the appropriate fatty Acyl-CoAs. The burst of alcohol that is apparent when QR worker glands are incubated in vitro indicates that the reduction step is normally blocked in these workers. Hydrocarbons may be formed from similar fatty acids precursors by elimination of the carboxyl carbon, but how their production is regulated remains elusive.

\section{DUFOUR'S GLAND - IS IT A SOURCE OF QUEEN SIGNAL?}

Both caste specificity and the biosynthetic plasticity expressed in the Dufour's gland raise questions regarding its function, and the social mechanisms regulating its activity. Queen-worker conflict over male production is a common feature in social insects, and worker-born males are observed in many species. In honeybees, however, it seems that the queen has almost absolute dominance over male production. The successful domination can be explained by kin selection theory. Since the queen honeybee is multiply inseminated, it is in the best interest of the workers to rear brothers (the queen's sons, average relatedness $=0.25$ ) rather than nephews (their nestmates' sons, average relatedness $=0.175)$. This has resulted in the evolution of selective elimination of worker-born eggs by the workers in the colony (Woyciechowski and Lomnicki, 1987), a phenomenon later called worker policing (Ratnieks, 1988). Egg policing requires the evolution of a discriminatory ability between queen- and worker-born eggs, whether tactile or chemical. It was suggested that egg discrimination 
is chemically based, and that Dufour's gland is the source of such substances (Ratnieks, 1995). Three predictions stem from this hypothesis: 1 . Dufour's gland secretion is caste specific; 2 . the glandular secretion is found on the eggs; and 3. application of the queen secretion on worker-laid eggs protects them from policing.

Dufour's gland secretion is, indeed, caste specific, queen glands possesses esters that are not present in QR workers, meeting the first prediction. However, glandular plasticity raises doubts regarding the role of Dufour's gland as an egg-marking pheromone, since QL egg-laying workers possess the major queen esters in their secretion, thus mimicking the queen glandular composition. Dufour's gland of QR egg-laying workers has not yet been studied, and it is still not clear whether such workers do produce these esters. Only if ester biosynthesis is inhibited in all QR workers (including potential egg-laying) can Dufour's gland secretion be effective as a queen egg-marking pheromone.

Egg coating analysis (Katzav-Gozansky et al., 2001b) revealed a massive amount of hydrocarbons that rendered the detection of esters very difficult. However, the esters were detected, albeit in very small amounts, once the bulk of hydrocarbons was removed from the extract by column chromatography. Queen Dufour's esters were also detected in queen abdominal tips, indicating that the secretion oozes out of the gland and spreads over the cuticular area of the tip. It seems plausible therefore that the eggs are not actively marked during deposition, but may be passively contaminated by the queen Dufour's gland secretion.

Worker policing, the selective removal of worker- but not queen-laid eggs, was tested by inserting two combs with worker-laid and queen-laid eggs side by side into a "discriminator colony" and monitoring egg removal after $24 \mathrm{~h}$ (Katzav-Gozansky et al., $2001 \mathrm{~b}$ ). The results of these experiments revealed that policing occurs whether the discriminatory colony is QR or QL. The occurrence of worker policing under QL conditions is intriguing. Theoretically, policing should persist under QL condition as long as queen eggs are still present. Moreover, it should neutralize selfish workers that begin ovipositing even while worker reproduction is still costly to the colony, before social breakdown decreases successful brood rearing (Page and Erickson, 1988). On the other hand, under a hopeless QL situation (absence of diploid brood that enables the replacement of the lost queen) when ovary development has occurred in the QL workers, policing should break down (Miller and Ratnieks, 2001). Under these QL conditions, male production is advantageous to the colony, irrespective of the workers that laid them. We have tested policing under complete QL hopeless situation (broodless groups). Because the absence of the queen is sensed by the workers within a short time (Juska et al., 1981), it is probable that workers in our set-up started to develop ovaries immediately after becoming QL. Under these conditions, it is predicted that worker policing will break down since rearing males is the only reproductive means available to such colonies. However, since rearing sons is still more profitable than nephews, it is also predicted that worker-worker conflict will erupt. The fact that QL workers still preferred queen over worker eggs indicates that the response to the queen signal is context-independent. It appears that the signal emanating from queen eggs was still able to elicit the preprogrammed response of these workers, despite the switch in their social conditions. This finding provides a nice example for the proximate mechanism (queen egg signal) overcomings the ultimate cause for its evolution (worker inclusive fitness).

To assess the role of Dufour's gland secretion in worker policing, we conducted two types of experiments. In the first, worker-laid eggs were treated with queen's secretion and introduced into the discriminator colony along with queen-laid eggs (testing whether treated worker eggs successfully mimic queen eggs). In the second experiment, treated worker-eggs were compared to non-treated worker-eggs ("upgrading" workers eggs to a "queen-egg status" with glandular secretion). Neither the queen's Dufour's gland secretion nor its synthetic ester constituents protected worker-laid eggs from oophagy (Fig. 3). It should be noted that when worker-laid eggs were inserted simultaneously with queen-laid eggs, the level of 


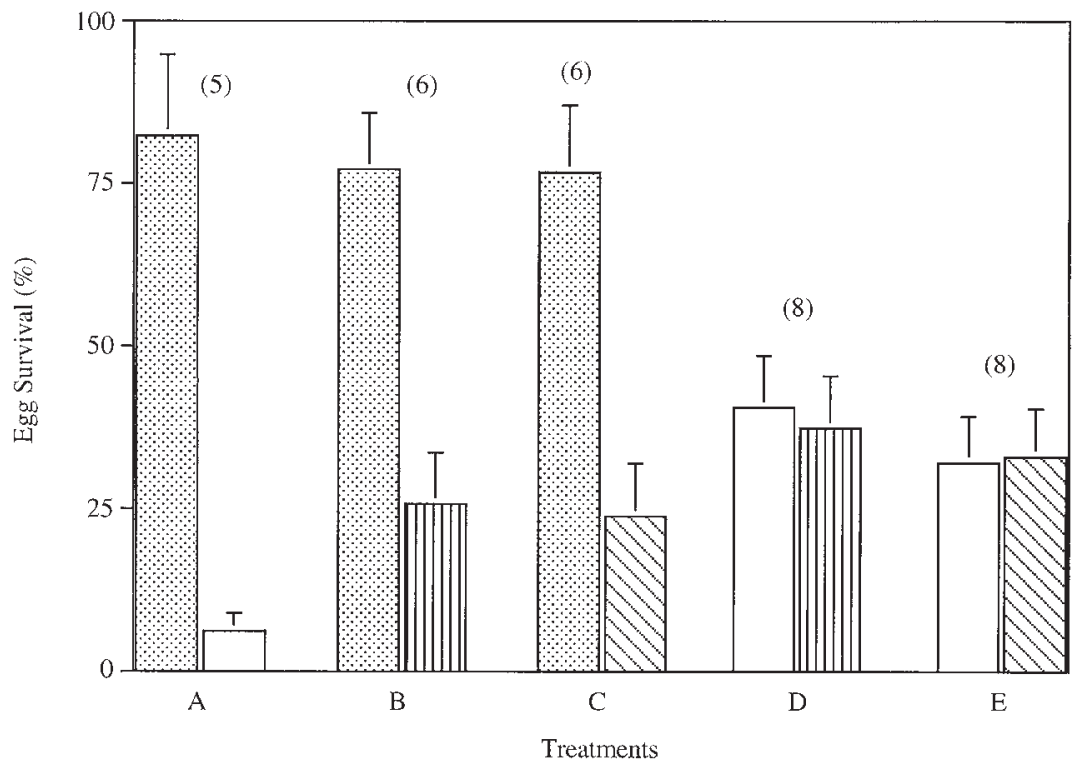

combs containing diploid queen-laid eggs sprayed with cthanol

W combs containing haploid worker-laid eggs sprayed with queens ' Dufour's gland

combs containing haploid worker-laid eggs sprayed with ethanol

Figure 3. Egg removal after $24 \mathrm{~h}$ in treated combs inserted into QR discriminatory colonies (different egg type were introduced on different combs). $(\mathrm{n})=$ number of replicates. Based on Katzav-Gozansky et al., $2001 b$.

policing against worker-laid eggs was higher. It is therefore possible that police workers use queen-laid eggs as a reference signal for the presence of eggs laid by workers, the removal of which is adaptive.

The results of the above experiments are not consistent with an egg-marking pheromone role of Dufour's gland secretion. While the inability of queen secretion to protect worker eggs from policing provides direct evidence to that effect, glandular plasticity provides indirect support. The fact that QL workers produce the queen-specific esters, and more specifically the reconstitution of the biosynthetic ability of glands of QR workers incubated in vitro, points to the potentiality of $\mathrm{QR}$ workers to mimic queen Dufour's gland composition. If the glandular compounds constitute the egg-marking pheromones, these workers are predicted to lay eggs that are protected from worker policing.
QR egg laying workers are known in the cape honeybee Apis mellifera capensis, however, policing was not detected in these species (Moritz et al., 1999). Analyzing their Dufour's gland secretion can shed light on this phenomenon. The very low number of worker-born males per colony even in comparison to the number of egg-laying workers (which is also rather low) indicates that policing is very effective and further suggests that the queen marks the eggs with a secretion that workers are unable to mimic. The nature and source of this putative secretion remains to be found.

Nonetheless, Dufour's gland secretion may still function as a component of the queen signal. Several exocrine secretions that are caste specific, such as QMP (Slessor et al., 1988) and the tergal gland secretion (Blum, 1992; Wossler and Crewe, 1999) serve as queen signals that control, directly or indirectly, colonial 

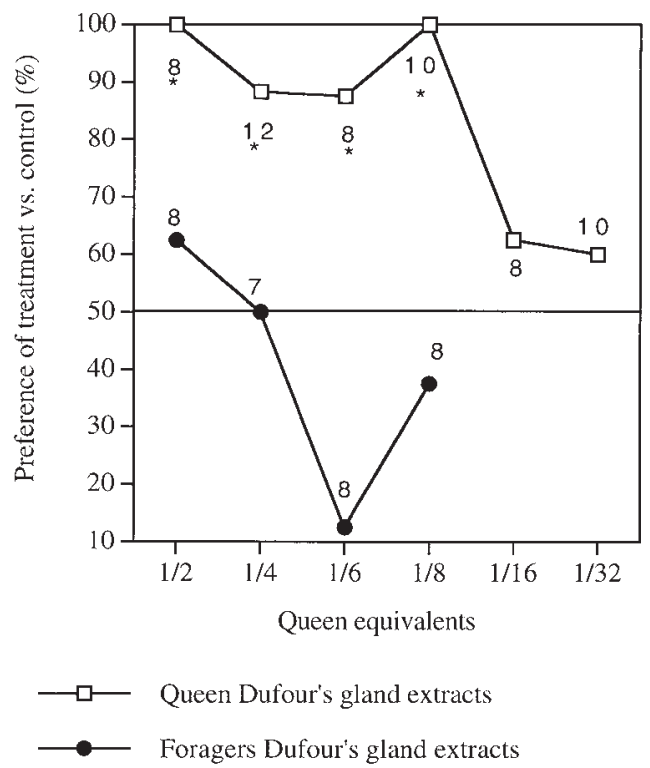

Figure 4. Attraction of worker honeybees to a nestmate worker applied with queen or worker Dufour's gland secretion at different concentrations. Data are presented as the preference, expressed as the percentage of tests in which the glandular secretion was preferred over the control. Statistical analysis was performed using Wilcoxon Signed Rank test. * Indicates concentrations for which the treatment was preferred significantly over the control. $\mathrm{n}$ - number of replicates. Based on Katzav-Gozansky et al., 2001b.

activities. For example, attraction of workers to the queen and retinue formation was first attributed only to the QMP (Free, 1987). However, it was found that demandibulated queens still evoked retinue responses (Winston and Slessor, 1992), and that the queen abdomen is much more effective in eliciting retinue behavior than the thorax (De Hazan et al., 1989). These results indicated the presence of another glandular source producing worker attractant in the queen abdomen. Pheromones also may have closely linked functions by having additive, synergistic, or overlapping effects. To investigate any possible releaser effect of Dufour's gland secretion, we conducted a bioassay for assessing worker attraction to the secretion. The results demonstrated that the queen glandular secretion, but not that of workers, is attractive to workers and that they form a retinue around the signal source (Fig. 4). The response to the secretion is shown as a dose response curve. The attraction response was weaker than the response to QMP and the doses needed to elicit attraction were much higher (Kaminski et al., 1990). These results imply that the secretion serves as an additional component in the array of pheromones that contribute to the formation of retinue around the honeybee queen (i.e. mandibular glands: Slessor et al., 1988; tergal glands: Wossler and Crewe, 1999).

\section{PERSPECTIVES}

In vitro studies revealed that there are no caste-specific physiological constraints on Dufour's gland secretion once it is detached from the regulatory factors, but the nature of this regulation, activation and/or inhibition, is still elusive. Based on the present data on the chemistry and physiology of the gland, it is hypothesized that in the presence of the queen or a queen signal (additional social signals may be involved as well) ester biosynthesis in worker Dufour's gland is inhibited. Once this signal is removed, the capacity of worker Dufour's gland to produce esters is restored following the necessary lag for the re-establishment of the appropriate biosynthetic capability. Since only females with developed ovaries (queens or egg-laying workers) possessed esters in their Dufour's gland secretion, there may be a link between physiological processes that take place during ovarian development and the activity of Dufour's gland that enables ester biosynthesis. The same processes may also affect other pheromonal glands like the mandibular glands, to alter their biosynthetic pathways. These findings open the way for research into a possible neuroendocrine control and help to bridge the gap between behavior, chemical ecology and neurobiology in honeybees. It also raises an interesting mechanistic question. In the case of both the mandibular glands and Dufour's gland, it appears that the presence of the queen signals inhibits the production of the queen-specific compounds in workers. What is the nature of this queen signal? Does a particular compound present in the queen inhibit its production in workers (i.e., queen esters inhibit the biosynthesis of these esters in workers), or 
are we witnessing a case of cross-reactivity (i.e., the compounds of queen mandibular glands inhibit Dufour's ester production and vice versa). Or, perhaps the complex of these secretions (along with other queen constituents) inhibit any queen-like expression in workers via a centralized sensor and/or neuroendocrine mechanism, as was already postulated for the action of mandibular glands (Velthuis, 1976).

Dufour's gland secretion is attractive to workers, but it may also serve other functions still to be explored, with is attractivity being merely a side effect of these other functions. The maintenance of reproductive dominance by a single queen in the honeybee colony is more complex than a one-pheromone one-signal system. It can, for example, signal the workers about queen quality and queen fecundity. Supercedure of an old, less fecund queen is common in honeybees (Winston, 1987), as in other eusocial Hymenoptera. Preference for the most fecund queen has previously been demonstrated in a number of ant species (Bartz and Hölldobler, 1982; Sommer and Hölldobler, 1995), and evidence for fertility signaling was reported in queens of Leptothorax sp. (Ortius and Heinze, 1999); albeit, the chemistry of these signals is still unknown. Identification of fecundity signals is extremely difficult because the less fecund queens are generally executed before overt signs can be observed. It was suggested by Pettis et al. (1997) that the honeybee colony is able to monitor its queen using a complex of several signals. QMP acts to indicate queen presence, while combs with eggs and young larvae provide additional fecundity signal, resulting in inhibition of worker reproduction. It is possible that Dufour's gland components present on queen eggs serve as this kind of signal. In addition, the secretion can serve to recognize potential egg-laying workers. It is likely that similar to queen secretion, worker secretion oozes out onto the abdominal cuticle, revealing the presence of esters in these workers. This may constitute the signal described by Visscher and Dukas (1995), who have shown that worker honeybees are able to detect in nestmates some characteristics correlated with ovarian development, and selectively attack nestmates with more developed ovaries. The retention of the queen-like biosynthetic abilities in worker Dufour's gland raises an interesting evolutionary question. Does it reflect an incomplete process of caste differentiation or did it specifically evolve later? The answer to these questions is not simple and lies in elucidating the complete pheromonal function of Dufour's gland secretion in queens and workers.

\section{ACKNOWLEDGMENTS}

This research was supported by THE ISRAEL SCIENCE FOUNDATION founded by the Israel Academy of Sciences and Humanities, and by the Fonds der chemischen Industrie, Germany. We thank Tovit Simon and Armin Ionescu for their technical help, N. Paz for editorial assistance. This manuscript is contribution No. (527/01) from the Volcani Center, Israel.

Résumé - La glande de Dufour de l'Abeille domestique - propriété caractéristique d'un nouveau signal de reines. Chez l'Abeille domestique, Apis mellifera L., les phéromones spécifiques des castes proviennent de diverses glandes exocrines et agissent sur de nombreuses activités de la colonie. La glande de Dufour, glande associée à l'appareil vulnérant, constitue une telle source de phéromone. Chez la reine, la glande de Dufour est plus grande et la quantité totale de la sécrétion est plus élevée que chez les ouvrières (Fig. 1). La glande de la reine présente aussi une diversité chimique plus grande que celle des glandes d'ouvrières (Tab. I, Fig. 2). Tandis que les glandes des ouvrières en présence de reine (ouvrières QR) ne contiennent que des $n$-alkanes impairs, les glandes de la reine possèdent aussi des esters à chaîne longue. Pourtant, il existe une plasticité dans l'expression glandulaire puisque les ouvrières pondeuses orphelines (ouvrières QL) produisent les esters caractéristiques de la reine. Les études de biosynthèse in vivo sont en accord avec la composition chimique de la glande chez les reines et les divers types d'ouvrières. Les études in vitro, par contre, montent une image différente : les glandes des ouvrières QR ont synthétisé les esters caractéristiques de la reine. L'étude in vitro a aussi montré une activation ou une restauration éventuelle de l'activité glandulaire une fois les facteurs inhibiteurs intrinsèques et extrinsèques éliminés. On a récemment suggéré que la sécrétion de la glande de Dufour pourrait agir comme phéromone de marquage de ponte aidant les ouvrières à différencier les œufs pondus par la reine de ceux pondus par les ouvrières (Ratnieks, 1995). L'analyse de la surface de l'œuf a montré la présence 
des esters de la glande de Dufour, mais seulement en très petites quantités. Les mêmes esters ont été détectés dans l'extrémité abdominale de la reine, indiquant que la sécrétion exsude de la glande et se répand sur la surface cuticulaire de l'extrémité. Ce résultat suggère que les œufs ne sont pas marqués activement mais contaminés passivement par la sécrétion au cours de la ponte. Notre expérience sur la police faite par les ouvrières n'a pas trouvé d'effet protecteur de la sécrétion de la glande de Dufour sur les œufs pondus par les ouvrières (Fig. 3), ce qui écarte la possibilité qu'elle serve de phéromone de marquage de ponte. Un test d'attraction utilisant la sécrétion glandulaire a montré que la sécrétion de la reine, mais pas celle des ouvrières, était attractive pour les ouvrières et que celles-ci formaient une cour autour de la source (Fig. 4). La découverte de la plasticité chimique de la sécrétion de la glande de Dufour a ouvert la voie à la recherche d'un éventuel contrôle endocrinien de la production de phéromone d'une part, et à la recherche des forces de sélection sous-tendant l'évolution sociale d'autre part. C'est une recherche qui comble les lacunes entre le comportement, l'écologie chimique et la neurobiologie chez l'Abeille domestique.

\section{glande de Dufour / signal de reine / spécificité de la caste / comportement de cour}

\section{Zusammenfassung - Die Dufour Drüse der Ho- nigbienen - charakteristische Eigenschaft eines neuen Signals der Königinnen. Die kastenspezifi- \\ Dufour Drüse / Honigbienen / Königinnen Signal / Kastenspezifität} schen Pheromone der Honigbiene, Apis mellifera L., stammen aus verschiedenen exokrinen Drüsen und beeinflussen viele der Volksaktivitäten. Eine mit dem Stachelapparat verbundene Drüse, die Dufour Drüse, stellt eine derartige Pheromonquelle dar. Die Dufourdrüsen sind bei den Königinnen größer und die Gesamtmenge ihres Sekrets ist höher (Abb. 1) als bei Arbeiterinnen. Die Drüsen der Königinnen weisen außerdem ein größere Vielfalt an chemischen Substanzen auf als die der Arbeiterinnen (Tab. I, Abb. 2). Während die Drüsen der weiselrichtigen Arbeiterinnen (QR) nur ungerade $n$-Alkanes enthalten, haben Königinnen zusätzlich langkettige Ester. Die Zusammensetzung des Sekrets ist jedoch veränderlich, denn weisellose eierlegende Arbeiterinnen (QL) produzieren ebenfalls die vor allem für Königinnen charakteristischen Ester. Biosynthetische in vivo - Versuche erbrachten mit der chemischen Zusammensetzung der Drüsen von Königinnen und verschiedenen Typen von Arbeiterinnen übereinstimmende Resultate. Versuche in vitro zeigten jedoch ein anderes Bild. Drüsen der QR Arbeiterinnen synthetisierten die für Königinnen charakteristischen Ester. Diese Untersuchungen weisen außerdem auf eine mögliche Aktivierung oder
Wiederherstellung der Drüsenaktivität hin, sobald diese einer intrinsischen oder extrinsischen Kontrolle entzogen war. Kürzlich wurde vermutet, dass das Sekret der Dufour Drüse als Pheromon zur Markierung dienen könnte, um den Arbeiterinnen eine Unterscheidung von Eiern der Königinnen und der Arbeiterinnen zu ermöglichen (Ratnieks, 1995). Die Analyse der Oberfläche der Eier zeigte das Vorhandensein der wichtigsten Ester der Dufour Drüse, wenn auch nur in sehr geringen Mengen. Auf der Spitze des Abdomens wurden dieselben Ester nachaustritt und sich über die Cuticula verteilt. Demnach würden die Eier passiv mit dem Sekret bei der Eiablage kontaminiert. Unser Experiment zur Eientfernung durch die Arbeiterinnen zeigte keinen Schutzeffekt von Dufourdrüsensekret für von Arbeiterinnen gelegte Eier (Abb. 3), damit kann dessen Funktion als Eimarkierungspheromon ausgeschlossen werden. Ein Attraktions-Biotest mit dem Drüsensekret zeigte, dass das Drüsensekret der Königin, aber nicht das der Arbeiterinnen attraktiv für Arbeiterinnen ist, und dass sie einen Hofstaat um die Pheromonquelle bilden (Abb. 4). Die Entdeckung der chemischen Plastizität des Sekrets der Dufourdrüse eröffnet die Möglichkeit von Untersuchungen zur neuroendokrinen Steuerung der Pheromonproduktion einerseits bis zu den der Sozialevolution zu Grunde liegenden Selektionsfaktoren anderseits.

\section{REFERENCES}

Allan S.A., Slessor K.N., Winston M.L., King G.G.S (1987) The influence of age and task specialization on the production and perception of honey bee pheromones, J. Insect Physiol. 33, 917-922.

Ayasse M., Marlovits T., Tengö J., Taghizadeh T., Francke W. (1995) Are there pheromonal dominance signals in the bumblebee Bombus hypnorum L. (Hymenoptera, Apidae)?, Apidologie 26, 163-180.

Bartz S.H., Hölldobler B. (1982) Colony founding in Myrmecocystus mimicus Wheeler (Hymenoptera: Formicidae) and the evolution of founders associations, Behav. Ecol. Sociobiol. 10, 137-147.

Billen J. (1987) New structural aspects of the Dufour's and venom glands in social insects, Naturwissenschaften 74, 340-341.

Blum M.S., Fales H.M., Jones T.H., Rinderer T.E., Tucker K.W. (1983) Caste-specific esters derived from the queen honey bee sting apparatus, Comp. Biochem. Physiol. 75B, 237-238.

Blum M.S. (1992) Honey bee pheromones, in: Graham J.M. (Ed.), The hive and the honey bee, Dadant and sons Hamilton, Illinois, pp. 373-400. gewiesen, was eher darauf deutet, dass das Sekret 
Boch R., Shearer D.A., Stone B.C. (1962) Identification of iso-amyl acetate as an active component in the sting pheromone of the honeybee, Nature 195, 1018-1020.

Boch R., Shearer D.A. (1966) Iso-pentyl acetate in stings of the honeybees of different ages, J. Apic. Res. 5, 65-70.

Breed M.D., Stiller T.M., Blum M.S., Page R.E. Jr. (1992) Honeybee nestmate recognition: Effects of queen fecal pheromones, J. Chem. Ecol. 18, 1633-1640.

Cane J.H. (1983a) Chemical evolution and chemosystematics of the Dufour's gland secretions of the lactone-producing bees (Hymenoptera: Colletidae, Halictidae and Oxeidae), Evolution 37, 657-674.

Cane J.H. (1983b) Preliminary chemosystematic of the Andrenidae and exocrine lipid evolution of the short-tongued bees (Hymenoptera: Apoidea), Syst. Zool. 32, 417-430.

Carlet G. (1890) Mémoire sur le venin et l'aiguillon de l'abeille, Ann. Sci. Nat. Zool. 9, 1-17.

Crewe M., Velthuis H.H.W. (1980) False queens: A consequence of mandibular gland signals in worker honeybee, Naturwissenschaften 67, 467-469.

De Hazan M., Lensky Y., Cassier P. (1989) Effect of queen honey bee (Apis mellifera L.) ageing on her atractivness to workers, Comp. Biochem. Physiol. 93A, 777-783.

Espelie K., Butz V.M., Dietz A. (1990) Decyl decanoate: a major component of the tergite glands of honeybee queens (Apis mellifera L.), J. Apic. Res. 29, 15-19.

Francis B.R., Blanton W.E., Littlefield J.L., Nunamaker R.A. (1989) Hydrocarbons of the cuticle and hemolymph of the adult honey bee, Ann. Entomol. Soc. Am. 82, 486-494.

Free J.B. (1987) Pheromones of social bees, Chapman and Hall, London.

Gary N.E. (1974) Pheromones that affect the behavior and physiology of honey bees, in: Birch M.C. (Ed.), Pheromones, American Elsevier, New York, pp. 200-221.

Hefetz A. (1987) The role of Dufour's gland secretion in bees, Physiol. Entomol. 12, 243-253.

Hefetz A. (1998) Exocrine glands and their products in non-apis bees: chemical, functional and evolutionary perspectives, in: Vandermeer C.R., Breed M., Espelie K., Winston M. (Eds.), Pheromones of Social Insects, Westview Press, Boulder Co., pp. 235-256.

Hefetz A., Tengö J., Lübke G., Francke W. (1993) Inter-colonial and intra-colonial variations in Dufour's gland secretion in the bumble bee species Bombus hypnorum (Hymenoptera: Apidae), in: Weise K., Gribakin F.G., Renninger G. (Eds.), Sensory Systems of Arthropods, Birkhauser Verlag, Basel, pp. 469-480.

Hefetz A., Taghizadeh T., Francke W. (1996) The exocrinology of the queen bumble bee Bombus terrestris (Hymenoptera: Apidae, Bombini), Z. Naturforsch. 51, 409-422.

Huang Z.Y., Robinson G.E., Borst D.W. (1994) Physiological correlates of division of labor among similarly aged honey bees, J. Comp. Physiol. 174, 731-739.

Juska A., Seeley T.D., Velthuis H.H.W. (1981) How honeybee queen attendants become ordinary workers, J. Insect Physiol. 27, 515-519.

Kaminski L.A., Slessor K.N., Winston M.L., Hay N.W., Borden J.H. (1990). Honeybee response to queen man- dibular pheromone in laboratory bioassays, J. Chem. Ecol. 16, 841-850.

Katzav-Gozansky T., Soroker V., Hefetz A., Cojocaru M., Erdmann D.H., Francke W. (1997a) Plasticity of caste-specific Dufour's gland secretion in the honey bee (Apis mellifera L.), Naturwissenschaften 84, 238-241.

Katzav-Gozansky T., Soroker V., Hefetz A. (1997b) The biosynthesis of Dufour's gland constituents in queens of the honeybee (Apis mellifera), Invertebr. Neurosci. 3, 239-243.

Katzav-Gozansky T., Soroker V., Hefetz A. (2000) Plasticity in caste-related exocrine secretion biosynthesis in the honey bee (Apis mellifera), J. Insect Physiol. 46, 993-998.

Katzav-Gozansky T., Soroker V., Ionescu A., Robinson G.E., Hefetz A. (2001a) Task-related chemical analysis of labial gland volatile secretion in worker honeybees (Apis mellifera ligustica), J. Chem. Ecol. 27, 919-926.

Katzav-Gozansky T., Soroker V., Ibarra F., Francke W., Hefetz A. (2001b) Dufour's gland secretion of the queen honeybee (Apis mellifera): an egg discriminator pheromone or a queen signal? Behav. Ecol. Sociobiol. 51, 76-86.

Kerr W.E., de Lello E. (1962) Sting gland in stingless bees have a vestigial character, J. N.Y. Entomol. Soc. 70, 190-214.

Miller D.G., Ratnieks F.L.W. (2001) The timing of worker reproduction and breakdown of policing behaviour in queenless honey bee (Apis mellifera L.) societies, Insectes Soc. 48, 178-184.

Moritz R.F.A., Kryger P., Allsopp M.H. (1999) Lack of Worker Policing in the cape honeybee (Apis mellifera capensis), Behaviour 136, 1079-1092.

Oldham N.J., Billen J., Morgan E.D. (1994) On the similarity of the Dufour gland secretion and the cuticular hydrocarbons of some bumblebees, Physiol. Entomol. 19, 115-123.

Ortius D., Heinze J. (1999) Fertility signaling in queens of north american ant, Behav. Ecol. Sociobiol. 45, 151-159.

Page R.E. Jr., Erickson E.H. (1988) Reproduction by worker honey bees (Apis mellifera L.), Behav. Ecol. Sociobiol. 23, 117-126.

Page R.E., Blum M.S., Fales H.M. (1988) o-Aminoacetophenone, a pheromone that repels honeybees (Apis mellifera L.), Experientia 44, 270-271.

Pettis J.S., Higo H.A., Pankiw T., Winston M.L. (1997) Queen rearing suppression in the honey bee - evidence for a fecundity signal, Insectes Soc. 44, 311-322.

Pickett J.A., Williams I.H., Smith M.C., Martin A.P. (1981) Nasonov pheromone of the honey bee, Apis mellifera L. (Hymenoptera, Apidae). Part III. Regulation of pheromone composition and production, J. Chem. Ecol. 7, 543-554.

Plettner E., Slessor K.N., Winston M.L., Robinson G.E., Page R.E. (1993) Mandibular gland components and ovarian development as measures of caste differentiation in the honey bee (Apis mellifera L.), J. Insect Physiol. 39, 235-240.

Plettner E., Slessor K.N., Winston M.L., Oliver J.E. (1996) Caste-selective pheromone biosynthesis in honeybees, Science 271, 1851-1853. 
Ratnieks F.L.W. (1988) Reproductive harmony via mutual policing by workers in eusocial hymenoptera, Am. Nat. 132, 217-236.

Ratnieks F.L.W. (1995) Evidence for a queen-produced egg-marking pheromone and its use in worker policing in the honey bee, J. Apic. Res. 34, 31-37.

Robinson G.E. (1985) Effects of a juvenile hormone analogue on honey bee foraging behavior and alarm pheromone production, J. Insect Physiol. 31, 277-282.

Schal C., Sevala V.L., Young H.P., Bachmann J.A.S. (1998) Sites of synthesis and transport pathways of insect hydrocarbons: Cuticle and ovary as target tissues, Am. Zool. 38, 382-393.

Shearer D.A. Boch R. (1965) 2-heptanone in the mandibular gland secretion of the honey bee, Nature 206, 530.

Sick M., Ayasse M., Tengö J., Engels W., Luebke G., Francke W. (1994) Host-parasite relationships in six species of Sphecodes bees and their halictid hosts: Nest intrusion, intranidal behavior, and Dufour's gland volatiles (Hymenoptera: Halictidae), J. Insect Behav. 7, 101-117.

Simpson J., Riedel I.B.M., Wilding N. (1968) Invertase in the hypopharyngeal glands of the honeybee, J. Apic. Res. 7, 29-36.

Slessor K.N., Kaminski L.A., King G.G.S, Borden J.H., Winston M.L. (1988) Semiochemical basis of the retinue response to queen honey bees, Nature 332, 354-356.

Slessor K.N., Kaminski L.A., King G.G.S., Winston M.L. (1990) Semiochemical of the honey bee queen mandibular glands, J. Chem. Ecol. 16, 851-860.

Sommer K., Hoelldobler B. (1995) Colony founding by queen association and determinants of reduction in queen number in the ant Lasius niger, Anim. Behav. 50, 287-294.

Soroker V., Vienne C., Hefetz A., Nowbahari E. (1994) The postpharyngeal gland as a "gestalt" organ for nestmate recognition in the ant Cataglyphis niger, Naturwissenschaften 81, 510-513.

Stanley-Samuelson D.W., Jurenka R.A., Cripps C., Blomquist G.J., de Renobales M. (1988) Fatty acids in insects: Composition, metabolism, and biological significance, Arch. Insect Biochem. Physiol. 9, 1-33.

Tengö J., Hefetz A., Bertsch A., Schmitt U., Lübke G., Francke W. (1991) Species specificity and complexity of Dufour's gland secretion of bumble bees, Comp. Biochem. Physiol. 99B, 641-646.

Trojan E. (1930) Die Dufoursche Drüse bei Apis mellifeca Z., Morphol. Ökol. Tiere. 19, 678-685.

Velthuis H.H.W. (1976) Egg laying, aggression and dominance in bees, Proc. XI Int. Congr. Entomol. Washington DC, pp. 436-449.

Visscher P.K., Dukas R. (1995) Honey bees recognize development of nestmates' ovaries, Anim. Behav. 49, 542-544.

Winston M.L. (1987) The Biology of the Honey Bee, Harvard University Press, Cambridge, Massachusetts, London, England.

Winston M.L. (1992) The honey bee colony: life history, in: Graham J.M. (Ed.), The hive and the honey bee, Dadant and sons Hamilton, Illinois, pp. 73-102.

Winston M.L., Slessor K.N. (1992) The essence of royalty: Honey bee queen pheromone, Am. Sci. 80, 374-385.

Wossler T.C., Crewe R.M. (1999a) Mass spectral identification of the tergal gland secretions of female castes of two African hony bee races (Apis mellifera), J. Apic. Res. 38, 137-148.

Wossler T.C., Crewe R.M. (1999b) The releaser effects of tergal gland secretion of queen honybees (Apis mellifera), J. Insect Behav. 12, 343-351.

Woyciechowski M., Lomnicki A. (1987) Multiple mating of queens and sterility of workers among eusocial Hymenoptera, J. Theor. Biol. 128, 317-327. 